Latin America Since the Left Turn 
DEMOCRACY, CITIZENSHIP, AND CONSTITUTIONALISM

Rogers M. Smith and Mary L. Dudziak, Series Editors 


\title{
Latin America Since the Left Turn
}

\author{
Edited by \\ Tulia G. Falleti \\ and \\ Emilio A. Parrado
}

\section{$\overline{\text { PENN }}$}

UNIVERSITY OF PENNSYLVANIA PRESS

PHILADELPHIA 
Copyright (@ 2018 University of Pennsylvania Press

All rights reserved. Except for brief quotations used for purposes of review or scholarly citation, none of this book may be reproduced in any form by any means without written permission from the publisher.

$$
\begin{gathered}
\text { Published by } \\
\text { University of Pennsylvania Press } \\
\text { Philadelphia, Pennsylvania 19104-4112 } \\
\text { www.upenn.edu/pennpress }
\end{gathered}
$$

Printed in the United States of America on acid-free paper $10958 \begin{array}{lllllll}10 & 9 & 5 & 4 & 3 & 2 & 1\end{array}$

\section{Library of Congress Cataloging-in-Publication Data}

Names: Falleti, Tulia Gabriela, editor. | Parrado, Emilio A., editor.

Title: Latin America since the left turn / edited by Tulia G. Falleti and Emilio A. Parrado.

Other titles: Democracy, citizenship, and constitutionalism.

Description: 1st edition. | Philadelphia : University of Pennsylvania Press, [2017] | Series: Democracy, citizenship, and constitutionalism | Includes bibliographical references and index.

Identifiers: LCCN 2017010470 | ISBN 9780812249712 (hardcover)

Subjects: LCSH: Latin America-Economic conditions-History-21st century. | Latin America-Politics and government-History-21st century. | New Left-Latin America.

Classification: LCC F1414.3 .L38 2017 | DDC 980.04-dc23

LC record available at https://lccn.loc.gov/2017010470 